\title{
Upregulation of NETO2 gene in colorectal cancer
}

\author{
Maria S. Fedorova ${ }^{1 \dagger}$, Anastasiya V. Snezhkina ${ }^{1 \dagger}$, Elena A. Pudova', Ivan S. Abramov', Anastasiya V. Lipatova', \\ Sergey L. Kharitonov', Asiya F. Sadritdinova', Kirill M. Nyushko², Kseniya M. Klimina², Mikhail M. Belyakov², \\ Elena N. Slavnova², Nataliya V. Melnikova', Maria A. Chernichenko², Dmitry V. Sidorov², Marina V. Kiseleva², \\ Andrey D. Kaprin², Boris Y. Alekseev², Alexey A. Dmitriev ${ }^{1}$ and Anna V. Kudryavtseva ${ }^{1,2^{*}}$
}

From Belyaev Conference

Novosibirsk, Russia. 07-10 August 2017

\begin{abstract}
Background: Neuropilin and tolloid-like 2 (NETO2) is a single-pass transmembrane protein that has been shown primarily implicated in neuron-specific processes. Upregulation of NETO2 gene was also detected in several cancer types. In colorectal cancer (CRC), it was associated with tumor progression, invasion, and metastasis, and seems to be involved in epithelial-mesenchymal transition (EMT). However, the mechanism of NETO2 action is still poorly understood.

Results: We have revealed significant increase in the expression of NETO2 gene and deregulation of eight EMT-related genes in CRC. Four of them were upregulated (TWIST1, SNAIL1, LEF1, and FOXA2); the mRNA levels of other genes (FOXA1, BMP2, BMP5, and SMAD7) were decreased. Expression of NETO2 gene was weakly correlated with that of genes involved in the EMT process.

Conclusions: We found considerable NETO2 upregulation, but no significant correlation between the expression of NETO2 and EMT-related genes in CRC. Thus, NETO2 may be involved in CRC progression, but is not directly associated with EMT.
\end{abstract}

Keywords: Colorectal cancer, NETO2, Epithelial-mesenchymal transition, Gene expression, QPCR

\section{Background}

Colorectal cancer (CRC) is the third most common malignancy in developed countries, and furthermore, its incidence rate has continuously increased over the past few decades [1]. While early-stage CRC can be effectively treated with radical surgery, approximately $20 \%$ of CRC patients present with advanced-stage disease at the time of initial diagnosis. These patients frequently have metastases that result in increased risk of death even after radical surgery [2]. CRC is characterized by multiple genetic and epigenetic changes that affect metabolic

\footnotetext{
* Correspondence: rhizamoeba@mail.ru

${ }^{\dagger}$ Equal contributors

'Engelhardt Institute of Molecular Biology, Russian Academy of Sciences, Moscow, Russia

${ }^{2}$ National Medical Research Radiological Center, Ministry of Health of the Russian Federation, Moscow, Russia

Full list of author information is available at the end of the article
}

and signaling pathways [3-6]. For instance, cancer cells have a higher glycolytic rate than normal ones [7-9], and, as a consequence, the terminal glycolytic metabolite lactate is exported to the extracellular matrix contributing the extracellular acidosis [10]. The acidic extracellular $\mathrm{pH}\left(\mathrm{pH}_{e}\right)$, in turn, can induce epithelial-mesenchymal transition (EMT) in carcinoma models and is closely associated with tumor metastasis [11, 12]. Thus, in addition to improving the current understanding of the mechanisms underlying CRC metastasis, it is important to identify novel components of EMT process that may be the potential biomarkers of the disease progression and can further contribute to both the selection of optimal treatment options and effective treatment monitoring for patients with CRC.

NETO2 gene is localized on chromosome 16 and encodes a transmembrane glycoprotein of unknown 
function. It has been shown that the abundant expression of NETO2 protein in neurons is essential for proper neurological function [13, 14]. Initially, NETO2 was believed to be a brain-specific protein $[15,16]$; however, recent studies described overexpression of NETO2 in several types of cancer, including renal, lung, colon, and cervical carcinomas [17]. Accordingly, $\mathrm{Hu}$ et al. recently suggested high expression of NETO2 as a potential biomarker of both advanced tumor progression and poor prognosis in patients with CRC [18].

In the present study, we hypothesized that the association of NETO2 overexpression with tumor progression, invasion, and metastasis may be indicative of its involvement in the epithelial-mesenchymal transition in CRC. To investigate the validity of this hypothesis, we evaluated whether NETO2 expression was correlated with that of genes established to mediate the EMT process.

\section{Methods}

\section{Tissue samples}

A total of 44 CRC and matched morphologically normal tissue samples, which were obtained after surgical resection, but prior to patient treatment with radiation and/ or chemotherapy, were frozen and stored in liquid nitrogen until use. All CRC samples were classified according to the American Joint Committee on Cancer (AJCC) staging system [19], and only those samples comprising $70 \%$ or more tumor cells were selected for analysis. Written informed consent was obtained from all patients for participation in the present study, which was approved by Herzen Moscow Cancer Research Institute - branch of National Medical Research Radiological Center, Ministry of Health of Russia Federation (Moscow, Russia), and conducted in strict accordance with the principles outlined in the Declaration of Helsinki (1964). Clinicopathologic characteristics of the CRC patients are shown in Table 1.

\section{RNA isolation and CDNA synthesis}

Total RNA was isolated from the frozen tissue samples using RNeasy Mini kit (Qiagen, Germany) according to manufacturer's instructions. RNA quality was measured via the RNA Integrity Number (RIN) method using an Agilent RNA Bioanalyzer 2100 (Agilent Technologies, USA). RNA quantification was performed using a NanoDrop 1000 instrument (NanoDrop Technologies, USA). cDNA was synthesized from the isolated RNA using M-MLV Reverse Transcriptase (Thermo Fisher Scientific, USA) and random hexamers.

\section{Quantitative PCR (qPCR)}

Quantitative polymerase chain reaction was performed using TaqMan Assay (Thermo Fisher Scientific) primers and probes for target genes (NETO2:
Table 1 Clinicopathologic characteristics of the CRC patients

\begin{tabular}{ll}
\hline Characteristic & Total, $\mathrm{n}$ \\
\hline Gender & 23 \\
Male & 21 \\
Female & \\
Age (years) & 14 \\
$\leq 60$ & 30 \\
$>60$ & \\
Clinical stage & 2 \\
I & 11 \\
II & 15 \\
III & 16 \\
Distant metastases (Stage IV) & \\
Negative & 4 \\
Positive & 12 \\
\hline
\end{tabular}

Hs00983152_m1, TWIST1: Hs00361186_m1, SNAIL1: Hs00195591_m1, SNAIL2: Hs00161904_m1, ZEB1: Hs01566408_m1, ZEB2: Hs00207691_m1, LEF1: Hs01547250_m1, FOXA2: Hs00232764_m1, FOXA1: Hs04187555_m1, CDH1: Hs01023895_m1, STAT1: Hs00374280_m1, BMP2: Hs00154192_m1， BMP5: Hs00234930_m1, VIM: Hs00958111_m1, SMAD2: Hs00998187_m1, SMAD3: Hs00969210_m1, SMAD4: Hs00929647_m1, SMAD7: Hs00998193_m1). Primers and probes for reference genes, GUSB and RPN1, were previously described $[20,21]$. All qPCRs were carried out in triplicate in total reaction volume of $20 \mu \mathrm{L}$ using an AB 7500 Real-Time PCR System (Thermo Fisher Scientific) to achieve cycling conditions comprising $95{ }^{\circ} \mathrm{C}$ for $10 \mathrm{~min}$, followed by 40 cycles of $95{ }^{\circ} \mathrm{C}$ for $15 \mathrm{~s}, 60{ }^{\circ} \mathrm{C}$ for $60 \mathrm{~s}$, and $72{ }^{\circ} \mathrm{C}$ for $30 \mathrm{~s}$.

QPCR data were analyzed using Relative Quantitation (Thermo Fisher Scientific) software and ATG program taking into account the efficiency of the PCR amplification [22, 23]. The expression levels of target genes were normalized to those of the reference genes. Finally, relative $(\mathrm{T} / \mathrm{N})$ expression level of target genes was calculated using the $\Delta \Delta \mathrm{Ct}$ method [24]. Since the relative inner variability between the calculated mRNA levels of the reference genes was found to be less than two-fold, a variation in the expression of the target genes of twofold or greater was considered to be significant.

\section{Statistical analysis}

Inter- and intra-group comparisons were performed using non-parametric Wilcoxon/Mann-Whitney and Kruskal-Wallis tests. Spearman's rank correlation coefficient $\left(r_{s}\right)$ was used for revealing correlations between 
NETO2 and EMT-related gene expression. All statistical analyses were performed using PASW Statistics 18 (SPSS Inc., USA) software. A $p$-value $<0.05$ was considered to indicate statistical significance.

\section{Results}

\section{Upregulation of NETO2 gene in CRC}

QPCR analysis of the relative NETO2 mRNA level across the 44 CRC samples revealed that NETO2 expression was increased by a factor of $2-50$ in $41 \%(18 / 44)$ of cases (Fig. 1). In contrast, NETO2 expression was decreased by a factor of $2-25$ in $14 \%(6 / 44)$ of CRC samples. These results demonstrating a significant increase in the expression of NETO2 in the analyzed CRC samples are consistent with those of the previous study by Oparina et al. [17].

\section{Deregulation of EMT-related genes in CRC}

We performed an analysis of the relevant literature and selected 17 genes related to EMT process in CRC (Table 2). Using qPCR, mRNA levels of these genes were analyzed in 44 CRC samples (Table 3 ).

\section{TWIST1 gene}

Up to 26-fold increase in the expression of TWIST1 gene was revealed in the majority $(68 \%, 30 / 44)$ of CRC samples compared to matched normal tissues. In contrast, two CRC samples exhibited decreased TWIST1 expression from 4- to 6-fold. The mean value of relative mRNA level of TWIST1 gene was 2.8.

\section{SNAIL1 and SNAIL2 genes}

Quantitative analysis of SNAIL1 expression showed it to be significantly increased in $80 \%$ (35/44) of CRC cases. mRNA level of SNAI1 gene was decreased by a factor of 6 only in one sample. The expression of SNAIL 2 was found to be decreased by a factor of $2-25$ in $20 \%(9 / 44)$ of CRC samples, and increased by a factor of $2-3$ in $11 \%(5 / 44)$ of ones. The mean value of relative mRNA levels of SNAII and SNAIL2 genes were 3.3 and 1.2, respectively.

\section{ZEB1 and ZEB2 genes}

Analysis of $Z E B 1$ gene expression revealed it to be decreased by a factor of $2-48$ in $36 \%(16 / 44)$ and increased in 9\% (4/44) of CRC samples. The expression of ZEB2 gene was decreased in $45 \%(19 / 44)$ and increased in $7 \%(3 / 44)$ of CRC cases. The mean value of relative mRNA levels of ZEB1 and ZEB2 genes were 1.5 and 1.7 , respectively.

\section{LEF1 gene}

LEF1 gene expression was increased by a factor of $2-52$ in $75 \%(33 / 44)$ of CRC cases, and slightly decreased by a factor of two only in one sample. The mean value of relative mRNA level of $L E F 1$ gene was 3.9.

\section{FOXA1 and FOXA2 genes}

The analysis of FOXA1 and FOXA2 gene expression showed that while FOXA1 expression was decreased by a factor of $2-79$ in $52 \%(23 / 44)$ of CRC samples, FOXA2 expression was increased from 2- to 23-fold in 59\% (26/ 44) of cases. Up to 4-fold increase in the expression of FOXA1 gene was detected in $7 \%(3 / 44)$ of examined samples. FOXA2 gene was downregulated by a factor of $2-70$ in 5\% (2/44) of CRC cases. The mean value of relative mRNA levels of FOXA1 and FOXA2 genes were 2.1 and 2.5 , respectively.

\section{CDH1 gene}

The analysis of $C D H 1$ gene expression showed it to be decreased by a factor of $2-86$ in $16 \%$ (7/44) of CRC samples, and increased by a factor of two in 5\% (2/44) of cases. The mean value of relative mRNA level of $C D H 1$ gene was 1.3.

\section{STAT1 gene}

Quantification of STAT1 gene expression revealed it to be increased by a factor of $2-4$ in $25 \%(11 / 44)$ of cases, and decreased by a factor of 3 in 5\% (2/44) of CRC samples. The mean value of relative mRNA level of STAT1 gene was 1.4 .

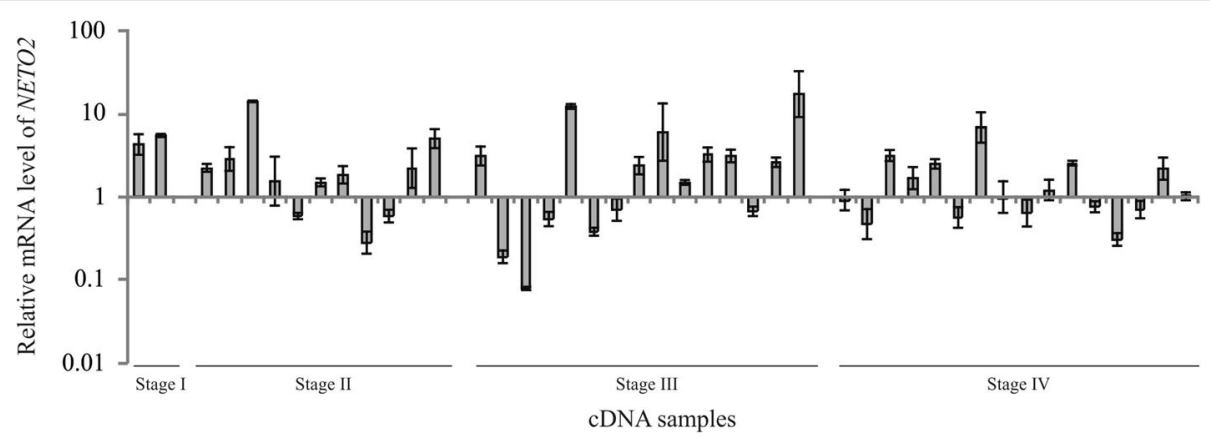

Fig. 1 Relative mRNA level of NETO2 gene in CRC. QPCR data 
Table 2 Genes involved in the epithelial-mesenchymal transition in CRC

\begin{tabular}{|c|c|c|}
\hline Gene & Description & References \\
\hline TWIST1 & $\begin{array}{l}\text { TWIST1 is a highly conserved basic helix-loop-helix (bHLH) transcription factor that regulates the EMT required } \\
\text { for neural crest migration during vertebrate embryonic development. TWIST1 expression is positively associated } \\
\text { with patient survival after curative CRC resection, and thus is a promising candidate biomarker of the disease progression. }\end{array}$ & $\begin{array}{l}33] \\
{[34]} \\
{[35]}\end{array}$ \\
\hline SNAIL1 & $\begin{array}{l}\text { SNAIL1 is a transcriptional regulator of E-cadherin, which suppression is critical to facilitate the EMT process. } \\
\text { SNAIL1 mRNA level is not detectable in the normal colon mucosa, but is upregulated in } 60-70 \% \text { of CRC. } \\
\text { Importantly, aberrant SNAIL1 expression in CRC has been shown to be associated not only with } \\
\text { poor patient prognosis, but also with a reduced relapse-free survival time. }\end{array}$ & $\begin{array}{l}{[36]} \\
{[37]} \\
{[38]} \\
{[39]} \\
{[40]}\end{array}$ \\
\hline SNAIL2 & $\begin{array}{l}\text { SNAIL2 has been implicated as an anti-apoptotic factor, and is thought to mediate the EMT process by } \\
\text { repressing E-cadherin transcription. Accordingly, SNAIL2 expression in human CRC cell lines has been shown }\end{array}$ & $\begin{array}{l}{[41]} \\
{[42]}\end{array}$ \\
\hline
\end{tabular}
to be correlated with critical EMT properties, including the loss of E-cadherin expression and an increase in both cell migration and invasion.

ZEB1 mediates the EMT pathway, and in fact has been shown to be not only sufficient to induce the EMT, but also necessary for maintaining the adapted mesenchymal phenotype. ZEB1 contains zinc finger clusters in both its $\mathrm{N}$ - and C-terminal regions, and a homeodomain in the central region. In CRC cells, ZEB1 has been shown to critically mediate the EMT, and thus may be an important regulator of CRC metastasis.

ZEB2 ZEB2 is a member of the Zfh1 family of two-handed zinc-finger transcription factors. It is frequently expressed in colon cancer, and has been shown by several previous studies to induce the EMT, and to facilitate cancer-cell metastasis, possibly via the repression and upregulation of E-cadherin and vimentin respectively.

LEF1 is critical for tumor-cell adhesion and/or migration, and thus, also for tumor invasion and metastasis. In addition, it plays a pivotal role in carcinogenesis and CRC progression, partly via its function in the LEF1/Bcatenin complex, which is a crucial effector of the Wnt signaling pathway. Increased LEF1 expression has been shown to be correlated with node and distant metastasis, and with an advanced tumor stage. Furthermore, LEF1 was shown to be involved in CRC invasion and metastasis.

FOXA1 and FOXA2 Forkhead box (FOX) protein A1 (FOXA1) is a transcription factor belonging to the FOX gene superfamily that mediates fundamental developmental and differentiation processes. Specifically, it modulates transcriptional programs in a tissue-dependent manner by inducing nucleosomal rearrangement, and by altering chromatin accessibility to the transcriptional machinery. FOXA1 has been shown to be overexpressed in CRC, and furthermore, to be positively associated with poor clinicopathological features. This suggests that its expression may be a promising candidate prognostic biomarker for patients with CRC. FOXA2 is a known key regulator of CRC metastasis to the liver.

$\mathrm{CDH1} \quad \mathrm{CDH1}$ gene encodes a classical cadherin. The E-cadherin-mediated cell adhesion system is required for both the EMT, and for cellular invasion, angiogenesis, and metastatic/tumor progression in many cancers, including CRC.

STAT1 STAT1 is a signal mediator that controls cell-death functions in the context of both pro-apoptotic and antiproliferative interferon-dependent signaling. It appears to exhibit tumor suppressive functions, and its activity has been shown to be associated with a favorable patient prognosis in some cancers.

BMP2 and BMP5 Bone morphogenetic proteins (BMPs) are the secreted ligands of the proteins belonging to the transforming growth factor beta superfamily (TGF $\beta$ ), and are important regulators of body-axis patterning during embryogenesis. In adult tissues, they regulate cell growth, apoptosis, and differentiation. The biological effects of BMPs have been predominantly studied in mesoderm-derived cells and tissues, and to a lesser degree, in epithelial cells and tissues. In general, BMPs are involved in the regulation of cancer progression and metastasis possibly through TGF- $\beta$ induced SMAD3-dependent EMT. Inactivation of BMP signaling increases the tumorigenicity of normal colon stem cells. filament protein, vimentin. Previous studies have shown that vimentin mediates both cellular structure and integrity. Furthermore, vimentin has also been demonstrated to mediate cell shape and motility during the EMT process, which is required for cancer-cell metastasis.

SMAD2, SMAD3, The SMADs are a family of structurally related signaling proteins that can be divided into three subgroups according SMAD4, and SMAD7 to their respective functions in TGF $\beta$ signaling. Specifically, the receptor-activated SMADs, including SMAD2 and SMAD3, are serine-phosphorylated following TGF-receptor complex formation. The unique SMAD4 Co-SMAD (which is common to both TGF $\beta$ and BMP signaling), then interacts with the phosphorylated SMAD2/SMAD3. The resulting heteropolymer migrates to the nucleus and complexes with tissue-specific transcription factors, thereby inducing the transcription of TGF $\beta$ target genes, including SMAD7. Finally, SMAD7, which is the only TGF $\beta$-specific anti-SMAD, prevents SMAD2/3 activation, thereby providing a transient TGF $\beta$ response in the form of a negative feedback loop. Immunohistochemical analysis has revealed the expression of SMADs during EMT process in CRC.

\section{BMP2 and BMP5 genes}

The expression of both $B M P 2$ and $B M P 5$ genes was suppressed in $75 \%(33 / 44)$ and $84 \%(37 / 44)$ of examined CRC samples, respectively. Increase in the $B M P 2$ gene expression was shown in only one sample (2\%), while that of BMP5 gene was detected in 7\% (3/44) of CRC cases. The mean value of relative mRNA levels of $B M P 2$ and BMP5 genes were 3.2 and 7.6, respectively. 
Table 3 Relative mRNA levels of EMT-related genes in CRC

\begin{tabular}{|c|c|c|c|}
\hline \multirow[t]{2}{*}{ Gene } & \multicolumn{2}{|c|}{ Frequency of mRNA level changes, \% } & \multirow{2}{*}{$\begin{array}{l}\text { Median of mRNA } \\
\text { level changes, } \\
\text { n-fold }\end{array}$} \\
\hline & $\begin{array}{l}\uparrow \text { increased } \\
\text { expression }\end{array}$ & $\begin{array}{l}\downarrow \text { decreased } \\
\text { expression }\end{array}$ & \\
\hline TWIST1 & $68(30 / 44)$ & $5(2 / 44)$ & $2.8 \uparrow$ \\
\hline SNAIL1 & $80(35 / 44)$ & $2(1 / 44)$ & $3.3 \uparrow$ \\
\hline SNAIL2 & $11(5 / 44)$ & $20(9 / 44)$ & $1.2 \downarrow$ \\
\hline ZEB1 & $9(4 / 44)$ & $36(16 / 44)$ & $1.5 \downarrow$ \\
\hline ZEB2 & $7(3 / 44)$ & $45(20 / 44)$ & $1.7 \downarrow$ \\
\hline LEF1 & $75(33 / 44)$ & $2(1 / 44)$ & $3.9 \uparrow$ \\
\hline FOXA1 & $7(3 / 44)$ & $52(23 / 44)$ & $2.1 \downarrow$ \\
\hline FOXA2 & $59(26 / 44)$ & $5(2 / 44)$ & $2.5 \uparrow$ \\
\hline $\mathrm{CDH1}$ & $5(2 / 44)$ & $16(7 / 44)$ & $1.3 \downarrow$ \\
\hline STAT1 & $25(11 / 44)$ & $5(2 / 44)$ & $1.4 \uparrow$ \\
\hline$B M P 2$ & $2(1 / 44)$ & $75(33 / 44)$ & $3.2 \downarrow$ \\
\hline BMP5 & $7(3 / 44)$ & $84(37 / 44)$ & $7.6 \downarrow$ \\
\hline VIM & $18(8 / 44)$ & $7(3 / 44)$ & $1.3 \uparrow$ \\
\hline SMAD2 & $0(0 / 44)$ & $11(5 / 44)$ & $1.4 \downarrow$ \\
\hline SMAD3 & $0(0 / 44)$ & $11(5 / 44)$ & $1.2 \downarrow$ \\
\hline SMAD4 & $0(0 / 44)$ & $23(10 / 44)$ & $1.5 \downarrow$ \\
\hline SMAD7 & $0(0 / 44)$ & $43(19 / 44)$ & $1.8 \downarrow$ \\
\hline
\end{tabular}

Note: Significant frequencies $(p<0.05)$ are marked in bold

\section{VIM gene}

The analysis of VIM expression showed it to be increased by a factor of $2-6$ in $18 \%(8 / 44)$ of CRC samples, and decreased by a factor of $2-4$ in $7 \%(3 / 44)$ of cases. The mean value of relative mRNA level of VIM gene was 1.3.

\section{SMAD2, SMAD3, SMAD4, and SMAD7 genes}

QPCR analysis showed SMAD2, SMAD3, SMAD4, and $S M A D 7$ mRNA levels to be decreased by a factor of 210 in $11-43 \%$ of the examined CRC samples. The mean value of relative mRNA levels of $S M A D 2, S M A D 3$, $S M A D 4$, and $S M A D 7$ genes were 1.4, 1.2, 1.5, and 1.8, respectively.

mRNA level of NETO2 is not correlated with that of EMTrelated genes in CRC

We used the Spearman's correlation coefficient to test the proposed hypothesis that NETO2 mRNA level in CRC correlates with that of the EMT-related genes. The results of this analysis showed that across the 44 analyzed CRC samples, 17 association pairs were identified between NETO2 and various genes involved in EMT, all of which exhibited weak relationship (Table 4). The most significant correlations were determined between NETO2 and SMAD7 expression $\left(r_{s}=0.25\right.$, $p<0.05)$ and between NETO2 and TWIST1 expression $\left(r_{s}=-0.24, p<0.05\right)$. These results indicate that the expression of NETO2 in CRC is only weakly correlated with that of EMT-related genes.

\section{Discussion}

The NETO2 gene encodes a transmembrane protein that is predominantly expressed in normal brain and retinal tissues. Thus, previous studies have primarily focused on NETO2 function in the context of neurobiology; in vitro analyses have revealed that NETO2 interacts with the GluK2 and GluK5 subunits of kainate receptors to significantly enhance kainate receptor-mediated signaling [25]. Recently, NETO2 has been shown to be involved in carcinogenesis. In a mutant cell line overexpressing metastasis-suppressor gene $N M 23-H 1$, which can reduce the metastatic potential of various types of cancer cells, NETO2 was amongst the nine genes identified to exhibit increased mRNA level [26]. NETO2 expression was reported to be upregulated in proliferating pediatric hemangiomas [27]. Notably, we previously demonstrated that NETO2 mRNA level is frequently overexpressed in kidney and lung cancers, and resultantly suggested it as a potential marker to early diagnosis of these diseases [17]. $\mathrm{Hu}$ and co-authors suggested both the potential significance of NETO2 expression in CRC carcinogenesis and its clinical relevance to the disease progression, invasion, and metastasis [18].

The EMT process is well established to be required not only for embryonic development, but also for cancer

Table 4 Spearman's correlation coefficients between mRNA levels of NETO2 and EMT-related genes

\begin{tabular}{ll}
\hline Gene & Spearman's correlation coefficient, $r_{s}$ \\
& NETO2 \\
\hline TWIST1 & -0.24 \\
SNAIL1 & -0.12 \\
SNAIL2 & -0.07 \\
ZEB1 & -0.05 \\
ZEB2 & 0.03 \\
LEF1 & 0.06 \\
FOXA1 & 0.06 \\
FOXA2 & 0.06 \\
CDH1 & 0.11 \\
STAT1 & 0.12 \\
BMP2 & 0.12 \\
BMP5 & 0.14 \\
VIM & 0.18 \\
SMAD2 & 0.21 \\
SMAD3 & 0.23 \\
SMAD4 & 0.24 \\
SMAD7 & 0.25 \\
\hline
\end{tabular}


progression and metastasis, since it facilitates the acquisition of invasive properties that allow cancer cells to enter the surrounding stroma and thereby generate a favorable tumor microenvironment [28-30]. Moreover, EMT process is known to be closely associated with cancer recurrence and chemoresistance. Nevertheless, the mechanisms underlying the involvement of EMT process in these events seem to vary significantly between cancer types.

To date, NETO2 is known to be associated with poor prognosis and metastasis in CRC, but not with the occurrence of EMT in this context. Thus, the present study investigated whether NETO2 expression in CRC was correlated with that of key genes involved in the EMT, including TWIST1, SNAIL1, SNAIL2, ZEB1, ZEB2, LEF1, FOXA2, FOXA1, CDH1, STAT1, BMP2, BMP5, VIM, SMAD2, SMAD3, SMAD4, and SMAD7. The results obtained in the work confirmed that NETO2 is overexpressed in CRC. It has also been demonstrated that several genes involved in the EMT process were upregulated in CRC compared to matched normal tissues, including TWIST1, SNAIL1, LEF1, and FOXA2, which mRNA levels were increased by an average factor of 2.8 , 3.3, 3.9, and 2.5 (median) respectively. Conversely, the mRNA levels of FOXA1, BMP2, BMP5, and SMAD7 genes were found to be decreased by a factor of 2.1, 3.2, 7.6, and 1.8 (median) respectively that is again in concordance with the results of recently studies [31, 32].

Notably, we found no significant correlation between the expression of NETO2 gene and that of the analyzed EMT-related genes in CRC. Thus, it is likely that NETO2 is involved in CRC progression, but is not directly associated with EMT.

\section{Conclusions}

NETO2 expression was found to be considerably increased, but not significantly correlated with the mRNA levels of EMT-related genes in CRC. Thus, while NETO2 overexpression may be indicative of poor clinical prognosis and metastasis, this is unlikely to be a direct result of alterations in the EMT process. Certainly, the molecular basis for and biological relevance of NETO2 upregulation in $\mathrm{CRC}$ requires further investigation.

\footnotetext{
Acknowledgments

Authors thank National Medical Research Center of Radiology for supplying tumor samples and clinicopathologic data; Vavilov Institute of General Genetics for the help with data analysis; Initium-Pharm, LTD for providing computational resources.

This work was performed using the equipment of EIMB RAS "Genome" center (http://www.eimb.ru/rus/ckp/ccu_genome_c.php).
}

\section{Funding}

This work and publication costs were funded by the Russian Science Foundation, grant 14-15-01083.
Availability of data and materials

All data generated or analyzed during this study are included in this published article.

\section{About this supplement}

This article has been published as part of BMC Genetics Volume 18

Supplement 1, 2017: Selected articles from Belyaev Conference 2017: genetics. The full contents of the supplement are available online at https://bmcgenet.biomedcentral.com/articles/supplements/volume-18supplement-1.

\section{Authors' contributions}

MSF, AVS, and AVK conceived and designed the work; MSF, AVS, ISA, AVL, SLK, AFS, KMN, MMB, ENS, MAC, and DVS performed the experiments; MSF, AVS, EAP, KMK, NVM, AAD, AVK, and MVK analyzed the data; MSF, EAP, AAD, $A V K, A D K$, and BYA wrote the manuscript. All authors read and approved the final manuscript

\section{Ethics approval and consent to participate}

The study was approved by The Ethics committee of Herzen Moscow Cancer Research Institute - branch of National Medical Research Radiological Center, Ministry of Health of Russia Federation. The study was done in accordance with the principles outlined in the Declaration of Helsinki (1964).

\section{Consent for publication}

Not applicable.

Competing interests

The authors declare that they have no competing interests.

\section{Publisher's Note}

Springer Nature remains neutral with regard to jurisdictional claims in published maps and institutional affiliations.

\section{Author details}

${ }^{1}$ Engelhardt Institute of Molecular Biology, Russian Academy of Sciences, Moscow, Russia. ${ }^{2}$ National Medical Research Radiological Center, Ministry of Health of the Russian Federation, Moscow, Russia. ${ }^{3}$ Vavilov Institute of General Genetics, Russian Academy of Sciences, Moscow, Russia.

Published: 28 December 2017

\section{References}

1. Markowitz SD, Bertagnolli MM. Molecular origins of cancer: molecular basis of colorectal cancer. N Engl J Med. 2009;361(25):2449-60.

2. Manfredi S, Lepage C, Hatem C, Coatmeur O, Faivre J, Bouvier AM. Epidemiology and management of liver metastases from colorectal cancer. Ann Surg. 2006;244(2):254-9.

3. Snezhkina AV, Krasnov GS, Zaretsky AR, Zhavoronkov A, Nyushko KM, Moskalev AA, Karpova IY, Afremova Al, Lipatova AV, Kochetkov DV, et al. Differential expression of alternatively spliced transcripts related to energy metabolism in colorectal cancer. BMC Genomics. 2016;17(Suppl 14):1011.

4. Kudryavtseva AV, Fedorova MS, Zhavoronkov A, Moskalev AA, Zasedatelev AS, Dmitriev AA, Sadritdinova AF, Karpova IY, Nyushko KM, Kalinin DV, et al. Effect of lentivirus-mediated shRNA inactivation of HK1, HK2, and HK3 genes in colorectal cancer and melanoma cells. BMC Genet. 2016;17(Suppl 3):156.

5. Snezhkina AV, Krasnov GS, Lipatova AV, Sadritdinova AF, Kardymon OL, Fedorova MS, Melnikova NV, Stepanov OA, Zaretsky AR, Kaprin AD, et al. The Dysregulation of polyamine metabolism in colorectal cancer is associated with Overexpression of C-Myc and C/EBPbeta rather than Enterotoxigenic Bacteroides Fragilis infection. Oxidative Med Cell Longev. 2016;2016: 2353560.

6. Fedorova MS, Kudryavtseva AV, Lakunina VA, Snezhkina AV, Volchenko NN, Slavnova EN, Danilova TV, Sadritdinova AF, Melnikova NV, Belova AA, et al. Downregulation of OGDHL expression is associated with promoter hypermethylation in colorectal cancer. Mol Biol. 2015;49(4):608-17.

7. Oparina NY, Snezhkina AV, Sadritdinova AF, Veselovskii VA, Dmitriev AA Senchenko VN, Mel'nikova NV, Speranskaya AS, Darii MV, Stepanov OA, et al. Differential expression of genes that encode glycolysis enzymes in kidney and lung cancer in humans. Russ J Genet. 2013;49(7):707-16. 
8. Krasnov GS, Dmitriev AA, Snezhkina AV, Kudryavtseva AV. Deregulation of glycolysis in cancer: glyceraldehyde-3-phosphate dehydrogenase as a therapeutic target. Expert Opin Ther Targets. 2013;17(6):681-93.

9. Krasnov GS, Dmitriev AA, Lakunina VA, Kirpiy AA, Kudryavtseva AV. Targeting VDAC-bound hexokinase II: a promising approach for concomitant anticancer therapy. Expert Opin Ther Targets. 2013;17(10):1221-33.

10. Huang R, Zong X. Aberrant cancer metabolism in epithelial-mesenchymal transition and cancer metastasis: mechanisms in cancer progression. Crit Rev Oncol Hematol. 2017;115:13-22.

11. Suzuki A, Maeda T, Baba Y, Shimamura K, Kato Y. Acidic extracellular pH promotes epithelial mesenchymal transition in Lewis lung carcinoma model. Cancer Cell Int. 2014;14(1):129.

12. Kato Y, Ozawa S, Miyamoto C, Maehata Y, Suzuki A, Maeda T, Baba Y. Acidic extracellular microenvironment and cancer. Cancer Cell Int. 2013;13(1):89.

13. Michishita M, Ikeda T, Nakashiba T, Ogawa M, Tashiro K, Honjo T, Doi K, Itohara S, Endo S. Expression of Btcl2, a novel member of BtCl gene family, during development of the central nervous system. Brain Res Dev Brain Res. 2004;153(1):135-42.

14. Finelli P, Sirchia SM, Masciadri M, Crippa M, Recalcati MP, Rusconi D, Giardino D, Monti L, Cogliati F, Faravelli F, et al. Juxtaposition of heterochromatic and euchromatic regions by chromosomal translocation mediates a heterochromatic long-range position effect associated with a severe neurological phenotype. Mol Cytogenet. 2012;5:16.

15. Stohr $\mathrm{H}$, Berger $\mathrm{C}$, Frohlich $\mathrm{S}$, Weber $\mathrm{BH}$. A novel gene encoding a putative transmembrane protein with two extracellular CUB domains and a lowdensity lipoprotein class a module: isolation of alternatively spliced isoforms in retina and brain. Gene. 2002;286(2):223-31.

16. Zhang W, St-Gelais F, Grabner CP, Trinidad JC, Sumioka A, Morimoto-Tomita M, Kim KS, Straub C, Burlingame AL, Howe JR, et al. A transmembrane accessory subunit that modulates kainate-type glutamate receptors. Neuron. 2009;61(3):385-96.

17. Oparina NYu, Sadritdinova AF, Snezhkina AV, Dmitriev AA, Krasnov GS, Senchenko VN, Melnikova NV, Belenikin MS, Lakunina VA, Veselovsky VA, et al. Increase in gene expression is a potential molecular genetic marker in renal and lung cancers. Russ J Genet. 2012;48(5):506-12.

18. Hu L, Chen HY, Cai J, Yang GZ, Feng D, Zhai YX, Gong H, Qi CY, Zhang Y, Fu H, et al. Upregulation of NETO2 expression correlates with tumor progression and poor prognosis in colorectal carcinoma. BMC Cancer. 2015;15:1006.

19. Hari DM, Leung AM, Lee JH, Sim MS, Vuong B, Chiu CG, Bilchik AJ. AJCC cancer staging manual 7th edition criteria for colon cancer: do the complex modifications improve prognostic assessment? J Am Coll Surg. 2013;217(2):181-90.

20. Krasnov GS, Dmitriev AA, Sadtritdinova AF, Fedorova MS, Snezhkina AV, Melnikova NV, Poteryakhina AV, Nyushko KM, Belyakov MM, Kaprin AD, et al. Evaluation of gene expression of Hexokinases in colorectal cancer with the use of bioinformatics methods. Biofizika. 2015;60(6):1050-6.

21. Krasnov GS, Oparina NYu, Dmitriev AA, Kudryavtseva AV, Anedchenko EA, Kondrat'eva TT, Zabarovsky ER, Senchenko VN. RPN1, a new reference gene for quantitative data normalization in lung and kidney cancer. Mol Biol. 2011:45(2):211-20.

22. Melnikova NV, Dmitriev AA, Belenikin MS, Koroban NV, Speranskaya AS, Krinitsina AA, Krasnov GS, Lakunina VA, Snezhkina AV, Sadritdinova AF, et al. Identification, expression analysis, and target prediction of flax Genotroph MicroRNAs under normal and nutrient stress conditions. Front Plant Sci. 2016;7:399.

23. Senchenko VN, Krasnov GS, Dmitriev AA, Kudryavtseva AV, Anedchenko EA, Braga EA, Pronina IV, Kondratieva TT, Ivanov SV, Zabarovsky ER, et al. Differential expression of CHL1 gene during development of major human cancers. PLoS One. 2011;6(3):e15612.

24. Dmitriev AA, Kudryavtseva AV, Krasnov GS, Koroban NV, Speranskaya AS, Krinitsina AA, Belenikin MS, Snezhkina AV, Sadritdinova AF, Kishlyan NV, et al. Gene expression profiling of flax (Linum usitatissimum L.) under edaphic stress. BMC plant biology. 2016;16(Suppl 3):237.

25. Straub C, Zhang W, Howe JR. Neto2 modulation of kainate receptors with different subunit compositions. J Neurosci. 2011;31(22):8078-82.

26. Horak CE, Lee JH, Elkahloun AG, Boissan M, Dumont S, Maga TK, ArnaudDabernat S, Palmieri D, Stetler-Stevenson WG, Lacombe ML, et al. Nm23-H1 suppresses tumor cell motility by down-regulating the lysophosphatidic acid receptor EDG2. Cancer Res. 2007;67(15):7238-46.

27. Calicchio ML, Collins T, Kozakewich HP. Identification of signaling systems in proliferating and involuting phase infantile hemangiomas by genome-wide transcriptional profiling. Am J Pathol. 2009;174(5):1638-49.
28. Ye X, Weinberg RA. Epithelial-Mesenchymal plasticity: a central regulator of cancer progression. Trends Cell Biol. 2015;25(11):675-86.

29. Iwatsuki M, Mimori K, Yokobori T, Ishi H, Beppu T, Nakamori S, Baba H, Mori M. Epithelial-mesenchymal transition in cancer development and its clinical significance. Cancer Sci. 2010;101(2):293-9.

30. Micalizzi DS, Farabaugh SM, Ford HL. Epithelial-mesenchymal transition in cancer: parallels between normal development and tumor progression. J Mammary Gland Biol Neoplasia. 2010;15(2):117-34.

31. Wang WJ, Yao Y, Jiang LL, Hu TH, Ma JQ, Ruan ZP, Tian T, Guo H, Wang SH, Nan KJ. Increased LEF1 expression and decreased Notch2 expression are strong predictors of poor outcomes in colorectal cancer patients. Dis Markers. 2013;35(5):395-405.

32. Ji Q, Liu X, Han Z, Zhou L, Sui H, Yan L, Jiang H, Ren J, Cai J, Li Q. Resveratrol suppresses epithelial-to-mesenchymal transition in colorectal cancer through TGF-beta1/Smads signaling pathway mediated snail/Ecadherin expression. BMC Cancer. 2015;15:97.

33. Yusup A, Huji B, Fang C, Wang F, Dadihan T, Wang HJ, Upur H. Expression of trefoil factors and TWIST1 in colorectal cancer and their correlation with metastatic potential and prognosis. World J Gastroenterol. 2017;23(1):110-20.

34. Hebrok M, Wertz K, Fuchtbauer EM. M-twist is an inhibitor of muscle differentiation. Dev Biol. 1994;165(2):537-44.

35. Ansieau S, Bastid J, Doreau A, Morel AP, Bouchet BP, Thomas C, Fauvet F, Puisieux I, Doglioni C, Piccinin S, et al. Induction of EMT by twist proteins as a collateral effect of tumor-promoting inactivation of premature senescence. Cancer Cell. 2008;14(1):79-89.

36. Kroepil F, Fluegen G, Vallbohmer D, Baldus SE, Dizdar L, Raffel AM, Hafner D, Stoecklein NH, Knoefel WT. Snail1 expression in colorectal cancer and its correlation with clinical and pathological parameters. BMC Cancer. 2013;13:145.

37. Franci C, Gallen M, Alameda F, Baro T, Iglesias M, Virtanen I, Garcia de Herreros A. Snail1 protein in the stroma as a new putative prognosis marker for colon tumours. PLoS One. 2009;4(5):e5595.

38. Loboda A, Nebozhyn MV, Watters JW, Buser CA, Shaw PM, Huang PS, Van't Veer $L$, Tollenaar RA, Jackson DB, Agrawal D, et al. EMT is the dominant program in human colon cancer. BMC Med Genet. 2011;4:9.

39. Kroepil F, Fluegen G, Totikov Z, Baldus SE, Vay C, Schauer M, Topp SA, Esch JS, Knoefel WT, Stoecklein NH. Down-regulation of CDH1 is associated with expression of SNAI1 in colorectal adenomas. PLoS One. 2012;7(9):e46665.

40. Roy HK, Smyrk TC, Koetsier J, Victor TA, Wali RK. The transcriptional repressor SNAIL is overexpressed in human colon cancer. Dig Dis Sci. 2005;50(1):42-6.

41. Tribulo C, Aybar MJ, Sanchez SS, Mayor R. A balance between the antiapoptotic activity of slug and the apoptotic activity of msx1 is required for the proper development of the neural crest. Dev Biol. 2004;275(2):325-42.

42. Kajita M, McClinic KN, Wade PA. Aberrant expression of the transcription factors snail and slug alters the response to genotoxic stress. Mol Cell Biol. 2004;24(17):7559-66.

43. Sun J, Ding W, Zhi J, Chen W. MiR-200 suppresses metastases of colorectal cancer through ZEB1. Tumour Biol. 2015;37(12):15501-7.

44. Schmalhofer O, Brabletz S, Brabletz T. E-cadherin, beta-catenin, and ZEB1 in malignant progression of cancer. Cancer Metastasis Rev. 2009;28(1-2):151-66.

45. Guo Y, Lang X, Lu Z, Wang J, Li T, Liao Y, Jia C, Zhao W, Fang H. MiR-10b directly targets ZEB1 and PIK3CA to curb Adenomyotic epithelial cell invasiveness via Upregulation of E-Cadherin and inhibition of Akt Phosphorylation. Cell Physiol Biochem. 2015;35(6):2169-80.

46. Bindels S, Mestdagt M, Vandewalle $C$, Jacobs $N$, Volders L, Noel A, van Roy F, Berx G, Foidart JM, Gilles C. Regulation of vimentin by SIP1 in human epithelial breast tumor cells. Oncogene. 2006;25(36):4975-85.

47. Peinado $\mathrm{H}$, Olmeda D, Cano A. Snail, Zeb and bHLH factors in tumour progression: an alliance against the epithelial phenotype? Nat Rev Cancer. 2007;7(6):415-28.

48. Comijn J, Berx G, Vermassen P, Verschueren K, van Grunsven L, Bruyneel E Mareel M, Huylebroeck D, van Roy F. The two-handed E box binding zinc finger protein SIP1 downregulates E-cadherin and induces invasion. Mol Cell. 2001;7(6):1267-78.

49. Lin AY, Chua MS, Choi YL, Yeh W, Kim YH, Azzi R, Adams GA, Sainani K, van de Rijn M, So SK, et al. Comparative profiling of primary colorectal carcinomas and liver metastases identifies LEF1 as a prognostic biomarker. PLoS One. 2011;6(2):e16636.

50. Hovanes K, Li TW, Munguia JE, Truong T, Milovanovic T, Lawrence Marsh J, Holcombe RF, Waterman ML. Beta-catenin-sensitive isoforms of lymphoid enhancer factor-1 are selectively expressed in colon cancer. Nat Genet. 2001;28(1):53-7. 
51. Moon RT, Kohn AD, De Ferrari GV, Kaykas A. WNT and beta-catenin signalling: diseases and therapies. Nat Rev Genet. 2004;5(9):691-701.

52. Katoh M, Igarashi M, Fukuda $H$, Nakagama $H$, Katoh M. Cancer genetics and genomics of human FOX family genes. Cancer Lett. 2013;328(2):198-206.

53. Hurtado A, Holmes KA, Ross-Innes CS, Schmidt D, Carroll JS. FOXA1 is a key determinant of estrogen receptor function and endocrine response. Nat Genet. 2011;43(1):27-33.

54. Ma W, Jiang J, Li M, Wang H, Zhang H, He X, Huang L, Zhou Q. The clinical significance of forkhead box protein A1 and its role in colorectal cancer. Mol Med Rep. 2016;14(3):2625-31.

55. Lehner F, Kulik U, Klempnauer J, Borlak J. The hepatocyte nuclear factor 6 (HNF6) and FOXA2 are key regulators in colorectal liver metastases. FASEB J. 2007;21(7):1445-62.

56. Palaghia M, Mihai C, Lozneanu L, Ciobanu D, Trofin AM, Rotariu A, Tarcoveanu F, Cijevschi Prelipcean C. E-cadherin expression in primary colorectal cancer and metastatic lymph nodes. Romanian J Morphol Embryol. 2016;57(1):205-9.

57. Klampfer $\mathrm{L}$. The role of signal transducers and activators of transcription in colon cancer. Front Biosci. 2008;13:2888-99.

58. Simpson JA, Al-Attar A, Watson NF, Scholefield JH, llyas M, Durrant LG. Intratumoral T cell infiltration, MHC class I and STAT1 as biomarkers of good prognosis in colorectal cancer. Gut. 2010;59(7):926-33.

59. Vishnubalaji R, Yue S, Alfayez M, Kassem M, Liu FF, Aldahmash A, Alajez NM. Bone morphogenetic protein 2 (BMP2) induces growth suppression and enhances chemosensitivity of human colon cancer cells. Cancer Cell Int. 2016;16:77.

60. Vishnubalaji R, Hamam R, Abdulla MH, Mohammed MA, Kassem M, AlObeed O, Aldahmash A, Alajez NM. Genome-wide mRNA and miRNA expression profiling reveal multiple regulatory networks in colorectal cancer. Cell Death Dis. 2015;6:e1614.

61. Fanale D, Barraco N, Listi A, Bazan V, Russo A. Non-coding RNAs functioning in colorectal cancer stem cells. Adv Exp Med Biol. 2016;937:93-108.

62. Lazarova DL, Bordonaro M. Vimentin, colon cancer progression and resistance to butyrate and other HDACis. J Cell Mol Med. 2016;20(6):989-93.

63. Gilles C, Polette M, Mestdagt M, Nawrocki-Raby B, Ruggeri P, Birembaut P, Foidart JM. Transactivation of vimentin by beta-catenin in human breast cancer cells. Cancer Res. 2003;63(10):2658-64.

64. Mendez MG, Kojima S, Goldman RD. Vimentin induces changes in cell shape, motility, and adhesion during the epithelial to mesenchymal transition. FASEB J. 2010;24(6):1838-51.

65. Lahat G, Zhu QS, Huang KL, Wang S, Bolshakov S, Liu J, Torres K, Langley RR, Lazar AJ, Hung MC, et al. Vimentin is a novel anti-cancer therapeutic target; insights from in vitro and in vivo mice xenograft studies. PLoS One. 2010; 5(4):e10105.

66. Boulay JL, Mild G, Lowy A, Reuter J, Lagrange M, Terracciano L, Laffer U, Herrmann R, Rochlitz C. SMAD7 is a prognostic marker in patients with colorectal cancer. Int J Cancer. 2003;104(4):446-9.

67. Boulay JL, Mild G, Lowy A, Reuter J, Lagrange M, Terracciano L, Laffer U, Herrmann R, Rochlitz C. SMAD4 is a predictive marker for 5-fluorouracilbased chemotherapy in patients with colorectal cancer. Br J Cancer. 2002; 87(6):630-4.

68. Kretzschmar M, Massague J. SMADs: mediators and regulators of TGF-beta signaling. Curr Opin Genet Dev. 1998;8(1):103-11.

69. Lee SJ, Yang CS, Kim DD, Kang YN, Kwak SG, Park JB, Cho CH, Park KK Microenvironmental interactions and expression of molecular markers associated with epithelial-to-mesenchymal transition in colorectal carcinoma. Int J Clin Exp Pathol. 2015;8(11):14270-82.

\section{Submit your next manuscript to BioMed Central and we will help you at every step:}

- We accept pre-submission inquiries

- Our selector tool helps you to find the most relevant journal

- We provide round the clock customer support

- Convenient online submission

- Thorough peer review

- Inclusion in PubMed and all major indexing services

- Maximum visibility for your research

Submit your manuscript at www.biomedcentral.com/submit
Biomed Central 